\title{
Correction to: Long-term safety and efficacy of vismodegib in patients with advanced basal cell carcinoma: final update of the pivotal ERIVANCE BCC study
}

\author{
Aleksandar Sekulic 1*, Michael R. Migden², Nicole Basset-Seguin ${ }^{3}$, Claus Garbe, Anja Gesierich ${ }^{4}$ Christopher D. Lao ${ }^{6}$, \\ Chris Miller ${ }^{7}$, Laurent Mortier ${ }^{8}$, Dedee F. Murrell ${ }^{9}$, Omid Hamid ${ }^{10}$, Jorge F. Quevedo ${ }^{11}$, Jeannie Hou ${ }^{12}$, \\ Edward McKenna ${ }^{12}$, Natalie Dimier ${ }^{13}$, Sarah Williams ${ }^{13}$, Dirk Schadendorf ${ }^{14}$, Axel Hauschild ${ }^{15}$ and for the ERIVANCE \\ BCC Investigators
}

\section{Correction to: BMC Cancer DOI 10.1186/s12885-017-3286-5}

Following publication of the original article [1], it was reported that the legend for Fig. 1 was incomplete. The complete figure legend is:

Fig. 1 Swimlane plot of time to response, treatment duration, and duration of follow-up for efficacy-evaluable patients who achieved response in the $\mathrm{mBCC}$ cohort (a), those in the laBCC cohort with treatment duration $>20$ months (b), and those in the laBCC cohort who were treated for $<20$ months (c). laBCC, locally advanced basal cell carcinoma; mBCC, metastatic basal cell carcinoma.

\footnotetext{
Author details

Mayo Clinic Scottsdale, 13400 East Shea Boulevard, Scottsdale, AZ 85259, USA. ${ }^{2}$ Departments of Dermatology and Head and Neck Surgery, The University of Texas MD Anderson Cancer Center, 1400 Pressler Street, Houston, TX 77030, USA. ${ }^{3}$ Service de Dermatologie, Hôpital Saint-Louis, 1 av claude Vellefaux, 75010 Paris, France. ${ }^{4}$ Studienzentrum Dermatologische Onkologie, Universitätsklinikum Tübingen, Liebermeisterstr. 25, 72074 Tübingen, Germany. ${ }^{5}$ Klinik für Dermatologie, Venerologie und Allergologie, Universitätsklinikum Würzburg, Josef-Schneider-Str. 2, 97080 Würzburg, Germany. ${ }^{6}$ University of Michigan, 1500 East Medical Center Drive, Ann Arbor, Ml 48109, USA. ${ }^{7}$ Department of Dermatology, University of Pennsylvania Medical Center, 3400 Civic Center Boulevard, Philadelphia, PA 19104. USA. ${ }^{8}$ Clinique de Dermatologie, Hôpital Claude Huriez, Inserm U1189, Lille, France. ${ }^{9}$ Dermatology Department, St George Clinical School, University of New South Wales, Grey Street, Sydney 2217, Australia. ${ }^{10}$ The Angeles Clinic and Research Institute, 1818 Wilshire Boulevard, California, Los Angeles, USA. ${ }^{11}$ Mayo Clinic, 200 First Street SW, Rochester, MN 55905, USA. ${ }^{12}$ Genentech,
}

* Correspondence: sekulic.aleksandar@mayo.edu

${ }^{1}$ Mayo Clinic Scottsdale, 13400 East Shea Boulevard, Scottsdale, AZ 85259

USA

Full list of author information is available at the end of the article
Inc., 1 DNA Way, South San Francisco, California 94080, USA. ${ }^{13}$ Roche Products Limited, Hexagon Place, 6 Falcon Way, Shire Park, Welwyn Garden City, Hertfordshire Al7 1TW, UK. ${ }^{14}$ Klinikum für Dermatologie, Venerologie und Allergologie, Universitätsklinikum Essen, Hufelandstrabe 55, 45147 Essen, Germany. ${ }^{15}$ Universitätsklinikum Schleswig-Holstein, Schittenhelmstr, 7, D-24 105 Kiel, Germany.

Received: 2 April 2019 Accepted: 2 April 2019

Published online: 18 April 2019

Reference

1. Sekulic A, et al. Long-term safety and efficacy of vismodegib in patients with advanced basal cell carcinoma: final update of the pivotal ERIVANCE BCC study. BMC Cancer. 2017;17:332. https://doi.org/10.1186/s12885-017-3286-5.

(c) The Author(s). 2019 Open Access This article is distributed under the terms of the Creative Commons Attribution 4.0 International License (http://creativecommons.org/licenses/by/4.0/), which permits unrestricted use, distribution, and reproduction in any medium, provided you give appropriate credit to the original author(s) and the source, provide a link to the Creative Commons license, and indicate if changes were made. The Creative Commons Public Domain Dedication waiver (http://creativecommons.org/publicdomain/zero/1.0/) applies to the data made available in this article, unless otherwise stated. 